\title{
LC-QTOF-MS Characterization, Antioxidant Activity, and In Vitro Toxicity of Medicinal Plants from the Tri-Than-Thip Remedy
}

\author{
Palika Wetchakul $\left(D,{ }^{1}\right.$ Piriya Chonsut, ${ }^{1}$ Chuchard Punsawad ${ }^{1 D},{ }^{2,3}$ \\ and Sineenart Sanpinit $\mathbb{D}$ \\ ${ }^{1}$ Department of Applied Thai Traditional Medicine, School of Medicine, Walailak University, \\ Nakhon Si Thammarat 80160, Thailand \\ ${ }^{2}$ Department of Medical Science, School of Medicine, Walailak University, Nakhon Si Thammarat 80160, Thailand \\ ${ }^{3}$ Research Center in Tropical Pathobiology, Walailak University, Nakhon Si Thammarat 80160, Thailand \\ Correspondence should be addressed to Sineenart Sanpinit; sineenart.sn@wu.ac.th
}

Received 23 September 2021; Revised 11 November 2021; Accepted 16 January 2022; Published 31 January 2022

Academic Editor: Giuseppe Malfa

Copyright (c) 2022 Palika Wetchakul et al. This is an open access article distributed under the Creative Commons Attribution License, which permits unrestricted use, distribution, and reproduction in any medium, provided the original work is properly cited.

Background. The world population has exhibited increased trust in folk medicine, including Thai folk medicine, for the treatment of various illnesses. However, the comparative antioxidant and cytoprotective activities against oxidative damage of Tri-ThanThip (Tri-TT), a Thai folk remedy, have not been reported. Objectives. The purpose of this study was to evaluate the antioxidant capacities of Tri-TT and its herbal constituents, Cassia fistula, Pithecellobium dulce, and Ficus benjamina. Methods. Extracts were obtained from Tri-TT and its herbal constituents. The free radical scavenging activities, cytotoxicity, ferric-reducing antioxidant power (FRAP), metal chelating activities, total phenolic compound (TPC) contents, and total flavonoid (TF) contents of Tri-TT extract were investigated, and qualitative analysis of the chemical composition of Tri-TT extract was performed by LC-QTOF-MS. Results. Tri-TT extract exhibited remarkable scavenging activities toward DPPH, ABTS, and superoxide anion radicals, with $\mathrm{IC}_{50}$ values of $0.081 \pm 0.00,0.021 \pm 0.00$, and $0.205 \pm 0.057 \mathrm{mg} / \mathrm{mL}$, respectively. The oxygen radical antioxidant capacity (ORAC) and FRAP values of Tri-TT were $6.499 \pm 0.67 \mu \mathrm{M} \mathrm{TE} / \mathrm{g}$ extract and $1,919.71 \pm 63.14 \mathrm{mM} \mathrm{FeSO} / \mathrm{mg}$ sample, respectively. $P$. dulce had the highest scavenging activities and antioxidant capacity followed by C. fistula and F. benjamina. The TPC and TF content of TriTT extract were $287.87 \mathrm{mg}$ equivalence $/ \mathrm{g}$ extract and $225.62 \mathrm{mg}$ catechin equivalent/g extract, respectively. The highest TPC was obtained from P. dulce, and TF content was observed in C. fistula. Using LC-QTOF-MS, a total of 25 compounds were tentatively identified in Tri-TT, including polyphenols such as luteolin, gallic acid, baicalein, apigenin, epicatechin, and ellagic acid. In addition, Tri-TT extract demonstrated nontoxicity (cell viability $>90 \%$ ) to Vero cells at the highest tested concentration of $80 \mu \mathrm{g} /$ $\mathrm{mL}$. Conclusion. This study demonstrated that the Tri-TT remedy is a promising candidate as a natural source of antioxidant activity, suggesting that the polyphenol content of plants may contribute to antioxidant activities.

\section{Introduction}

Free radicals include reactive oxygen species (ROS) as well as reactive nitrogen species (RNS). Within cells, ROS function as secondary messengers in intracellular signaling cascades involved in human diseases such as gastric ulcers, hypertension, preeclampsia, neurological disorders, atherosclerosis, inflammatory conditions, certain cancers, and the process of aging [1]. An antioxidant can delay or relieve and inhibit oxidative damage to a target molecule and its ability is to trap free radicals by acting as a free radical scavenger, chelating, and other mechanisms to prevent lipid oxidation, and carbonyl scavengers as a way to avoid lipid oxidation consequences antioxidants. Antioxidants mitigate the effects of free radicals and protect cells from damage. Plants are good sources of antioxidants, and herbs have been used medicinally since ancient times based on reports of folk medicine. Natural sources of antioxidants have been of interest to researchers, as they are inexpensive and natural [2]. In Thailand, many plants used in food and 
medicine have been reported as sources of natural antioxidants. From the types of remedies described in the Thai Pharmaceutical Textbook, herbal formulations are commonly added to Thai ancient household remedies [3]. Thai remedies have shown antioxidant capacity when studied as an herbal formulation, and subsequent deeper studies on their antioxidant activities revealed good antioxidant activity and a potential for development as natural dietary supplements, including Triphala and Jatu-phala-Tiga (JPT). A previous study reported that JPT has strong antioxidant activities, particularly the water extract of the polyherbal tonic. These findings rationalize further investigation of JPT infusions as a promising agent for antiaging and oxidative stress prevention [4]. The overall report generated interest in Thai drug formulas against free radicals from natural and Tri-Than-Thip (Tri-TT) remedies and is another interesting Thai drug formula.

The Tri-TT remedy is a group of herbs from Thai traditional medicine that have historically been used for nourishing breastfeeding mothers, healing wounds, and relieving diarrhea, and this remedy contains many parts of Cassia fistula, Pithecellobium dulce, and Ficus benjamina, which were reported to have good antioxidant capacity [5-7]. Although a previous study confirmed the good antioxidant ability of different parts of the herbal elements, there have been a few reports on the roots of the component herbs. Therefore, this study aimed to evaluate the antioxidant capacity and cytotoxicity of the Tri-TT remedy and its three individual botanical constituents.

\section{Materials and Methods}

2.1. Chemicals. 2,2-Diphenyl-1-picrylhydrazyl (DPPH), 2,2'azobis-2-methyl-propanimidamide, dihydrochloride (AAPH), 2,2,-azinobis [3-ethylbenzothiazoline-6-sulfonic acid]) (ABTS), ethylenediaminetetraacetic acid (EDTA), Trolox, gallic acid, sodium carbonate, hydrogen peroxide, phosphate buffered saline (PBS), nitrotetrazolium blue chloride, iron(II) chloride $\left(\mathrm{FeCl}_{2}\right)$, iron(III) chloride hexahydrate (ferric chloride), magnesium sulfate, and Folin-Ciocalteu reagent were purchased from Sigma-Aldrich (Mumbai, India). Acetic acid and hydrochloric acid were purchased from J. T. Baker (Haryana, India). Aluminum chloride $\left(\mathrm{AlCl}_{3}\right)$, potassium dihydrogen orthophosphate, potassium persulfate $\left(\mathrm{K}_{2} \mathrm{~S}_{2} \mathrm{O}_{8}\right)$, sodium acetate trihydrate, sodium carbonate anhydrous $\left(\mathrm{Na}_{2} \mathrm{CO}_{3}\right)$, sodium chloride $(\mathrm{NaCl})$, sodium nitrite $\left(\mathrm{NaNO}_{2}\right)$, sodium hydroxide $(\mathrm{NaOH})$, and sodium dihydrogen orthophosphate were purchased from Ajax Finechem (New South Wales, Australia). Dimethyl sulfoxide (DMSO) was purchased from Fisher Chemical (Chicago, United States). 2,4,6-Tris(2-pyridyl)-s-triazine (TPTZ) and 3-(2-pyridyl)-5,6-diphenyl-1,2,4-triazine- $4^{\prime}, 4^{\prime}$ disulfonic acid sodium salt (ferrozine) were purchased from Fluka (Buchs, Switzerland). Solvents, including ethanol and methanol, were obtained from Merck (Darmstadt, Germany). All reagents and chemicals used were of analytical reagent grade and purchased from commercial sources. Deionized water was used for sample preparation, dilution, and rinsing apparatus prior to analysis.
2.2. Preparation of the Tri-TT Remedy and Three Botanical Extracts. One kilogram of dried root powders of $P$. dulce, C. fistula, and F. benjamina was mixed together in a $1: 1: 1$ ratio to obtain Tri-TT. Briefly, both Tri-TT and individual plant ingredient powders were individually macerated with $1000 \mathrm{~mL}$ of ethanol at room temperature for 3 days, filtered through Whatman No. 1 filter paper, and dried using a vacuum rotary evaporator (Heidolph, Germany). All extracts were stored at $20^{\circ} \mathrm{C}$ until further experiments. The extraction yield of each plant extract was calculated as weight percent $(\% \mathrm{w} / \mathrm{w})[4]$ :

$$
\text { Extraction yield }(\%)=\frac{\text { weight of the dry extract }}{\text { weight of the initial dry material }} \times 100 \text {. }
$$

2.3. Free Radical Scavenging Activities. The antioxidant activity of the extracts was evaluated using the DPPH and ABTS assays described by Ghasemi Pirbalouti et al. [8]. For DPPH radical scavenging assays, $1 \mathrm{~mL}$ of sample extract was diluted in 2-fold increment to various concentrations (1.22 to $2500 \mu \mathrm{g} / \mathrm{mL}$ ), and $20 \mu \mathrm{L}$ of each sample at different concentrations was placed in a 96-well plate containing $80 \mu \mathrm{M}$ DPPH in ethanol solution $(180 \mu \mathrm{L})$. The 96 -well plate was incubated in the dark for approximately $30 \mathrm{~min}$ at room temperature. The absorbance of the solution was read at $520 \mathrm{~nm}$. Trolox was used as a positive control and used to construct a calibration curve, and half maximal inhibitory concentration $\left(\mathrm{IC}_{50}\right)$ values were calculated.

To generate $\mathrm{ABTS}^{+}, 2 \mathrm{mM}$ ABTS and $2.45 \mathrm{mM}$ potassium persulfate were mixed together at a volume ratio of $1: 1$, and then the mixture was stored in the dark at room temperature for $16 \mathrm{~h}$. The absorbance of the solution was maintained at $0.70 \pm 0.05$ at $734 \mathrm{~nm}$. Sample extracts $(10 \mu \mathrm{L})$ at various concentrations (between 1.22 and $2500 \mu \mathrm{g} / \mathrm{mL}$ ) were added to a 96-well plate, followed by the addition of $1 \mathrm{~mL}$ of $\mathrm{ABTS}^{+}$solution and incubation for $6 \mathrm{~min}$. The absorbance was read at $734 \mathrm{~nm}$. Trolox was used as a positive control and used to construct a calibration curve. Finally, the scavenging activity is expressed as the concentration that caused $50 \%$ inhibition of $\mathrm{ABTS}^{+}$, as in the DPPH assay:

$$
\text { scavenging activity }(\%)=\frac{\left[\mathrm{Ab}_{\text {control }}-\mathrm{Abs}_{\text {sample }}\right] \times 100}{\mathrm{Abs}_{\text {control }}} \text {. }
$$

2.4. Metal Chelating Activity. The ability of the polyherbal extracts to chelate ferrous ions was measured by a previously described colorimetric metal chelating activity (MCA) method [9]. Briefly, $0.1 \mathrm{mM} \mathrm{FeSO}(0.2 \mathrm{~mL})$ and $0.25 \mathrm{mM}$ ferrozine $(0.4 \mathrm{~mL})$ were added to $0.2 \mathrm{~mL}$ of plant extract with a concentration range of 0.03 to $62.50 \mathrm{mg} / \mathrm{mL}$. After incubation at room temperature for $10 \mathrm{~min}$, an increase in the absorbance of the stable ferrous-ferrozine complex was detected at $562 \mathrm{~nm}$. EDTA was used as a positive control. MCA was calculated using 
metal chelating activity $(\%)=\frac{\left[\mathrm{Ab}_{\text {control }}-\mathrm{Abs}_{\text {sample }}\right] \times 100}{A b s_{\text {control }}}$.

2.5. Single Electron Transfer-Based FRAP Assay. The ferricreducing antioxidant power (FRAP) activity of the plant extract was determined according to a previous study with minor modifications [10]. The FRAP working solution was freshly prepared by mixing $10 \mathrm{~mL}$ of $300 \mathrm{mM}$ acetate buffer, $1 \mathrm{~mL}$ of $10 \mathrm{mM}$ TPTZ solution, and $10 \mathrm{~mL}$ of $20 \mathrm{mM}$ ferric chloride. Twenty milliliters of each extract was diluted in ethanol to various concentrations of 0.625 to $1.35 \mathrm{mg} / \mathrm{mL}$, added to each well in a 96-well microtiter plate, and incubated at room temperature for $30 \mathrm{~min}$ in the dark. The absorbance of the solution was detected at $562 \mathrm{~nm}$ by the colored product from an intense blue color complex formed by the reduction of TPTZ to ferrous-TPTZ in the presence of electron donating antioxidants at low $\mathrm{pH}$, and the reducing capacity is expressed as $\mu \mathrm{M} \mathrm{Fe}_{2} \mathrm{SO}_{4} / \mathrm{mg}$ extract.

2.6. Superoxide Anion Radical Scavenging Activity. Superoxide anions can be found in the process of energy production in cells in the body, which leads to lipid peroxidation. Therefore, the superoxide anion scavenging ability and the capacity to reduce the rate of lipid peroxidation were evaluated. This activity was evaluated based on the reduction of NBT according to a previous report with minor modifications [11]. The riboflavin/methionine/illuminate system was used to generate superoxide anion radicals, which reduced NBT to form purple formazan $\left(\mathrm{NBT}^{2+}\right)$.

The reaction mixture contained $100 \mu \mathrm{L}$ of NBT $(400 \mu \mathrm{g} / \mathrm{mL})$ and $0.4 \mathrm{~mL}$ of a solution consisting of riboflavin $(30 \mu \mathrm{g} / \mathrm{mL})$, methionine $(30 \mu \mathrm{g} / \mathrm{mL})$, EDTA $(20 \mu \mathrm{g} / \mathrm{mL})$, and the plant extract at different concentrations (2-fold dilution; 4.88 to $156.25 \mu \mathrm{g} / \mathrm{mL}$ ) diluted in 0.05 M PBS (pH 7.4). Photoinduced superoxide radicals were initiated with illumination by a fluorescent lamp $(20 \mathrm{~W})$ at $25^{\circ} \mathrm{C}$ for $25 \mathrm{~min}$. After incubation, the absorbance was measured at $560 \mathrm{~nm}$. The scavenging activity is expressed as the concentration that caused 50\% inhibition of superoxide anion radicals $\left(\mathrm{IC}_{50} ; \mathrm{mg} / \mathrm{mL}\right)$. Catechin was used as a reference compound.

\subsection{Hydrogen Atom Transfer-Based Assay and Peroxyl Radical} Scavenging Assay (ORAC Assay). An oxygen radical antioxidant capacity (ORAC) assay with some modifications was used to evaluate the antioxidant activity of the extracts against peroxyl radicals generated from the thermal homolysis of AAPH [12]. The assay was carried out in blackwalled 96-well plates with PBS (pH 7.4). The standard was $25 \mathrm{~mL}$ of Trolox solution, and the samples were analyzed as $25 \mathrm{~mL}$ solutions at various concentrations of 0.2 to $100 \mu \mathrm{g} /$ $\mathrm{mL}$ (2-fold dilution). All experimental wells received $150 \mathrm{~mL}$ of sodium fluorescein $(40 \mathrm{nM})$. After $30 \mathrm{~min}$ of incubation at $37^{\circ} \mathrm{C}, 25 \mu \mathrm{L}$ of AAPH solution was added to the solution. The plate was placed into a microplate reader and analyzed with an excitation wavelength of $485 \mathrm{~nm}$ and emission wavelength of $535 \mathrm{~nm}$, every $5 \mathrm{~min}$ for $90 \mathrm{~min}$. The antioxidant capacity is expressed as Trolox equivalents per $\mu \mathrm{g}$ of extract ( $\mu \mathrm{M} \mathrm{TE} / \mu \mathrm{g} \mathrm{E})$. This activity was calculated using equations (4) and (5).

$$
\mathrm{AUC}=\left(\frac{R_{1}}{R_{1}}\right)+\left(\frac{R_{2}}{R_{1}}\right)+\left(\frac{R_{3}}{R_{1}}\right)+\cdots+\left(\frac{R_{n}}{R_{1}}\right),
$$

where $R_{1}$ is the fluorescence reading at the initiation of the reaction and $R_{n}$ is the last measurement.

$$
\text { Net } \mathrm{AUC}=\mathrm{AUC}_{\text {sample }}-\mathrm{AUC}_{\text {blank }} \text {. }
$$

2.8. Determination of TPC Content. The total phenolic compound (TPC) content in plant extracts was determined according to a previous study with minor modifications [13]. Briefly, $120 \mu \mathrm{L}$ of extract $(2.5 \mathrm{mg} / \mathrm{mL})$ was mixed with $1 \mathrm{~mL}$ of Folin-Ciocalteu reagent for $5 \mathrm{~min}$. Then, $1 \mathrm{~mL}$ of $20 \% \mathrm{w} / \mathrm{v}$ sodium carbonate solution was homogenously mixed and allowed to stand for $90 \mathrm{~min}$ in the dark at ambient temperature. Then, the absorbance was measured at $725 \mathrm{~nm}$. The TPC content was nitrotetrazolium determined with a calibrated curve of gallic acid and is expressed in terms of milligrams of gallic acid equivalents per gram of extract.

2.9. Determination of TF Content. To determine the total flavonoid (TF) content, the plant extracts were analyzed based on a previous study with minor modifications [14]. Briefly, $50 \mu \mathrm{L}$ of the plant extract $(2.5 \mathrm{mg} / \mathrm{mL})$ was combined with $300 \mu \mathrm{L}$ of $5 \%(\mathrm{w} / \mathrm{v})$ sodium nitrite, $300 \mu \mathrm{L}$ of $10 \%(\mathrm{w} / \mathrm{v})$ aluminum trichloride, and $4 \mathrm{~mL}$ of distilled water, after which the solution was homogenously mixed and incubated for $6 \mathrm{~min}$ at ambient temperature. The reaction was stopped with $2 \mathrm{~mL}$ of $1 \mathrm{M}$ sodium hydroxide after $5 \mathrm{~min}$. The absorbance was recorded at $510 \mathrm{~nm}$. The TF content is expressed as catechin equivalents per gram dry matter.

2.10. MTT Assay. The plant extracts were tested for in vitro cytotoxicity using Vero cells by a 3-(4,5-dimethylthiazol-2yl)-2,5-diphenyltetrazolium bromide (MTT) assay [15]. Cells $\left(1 \times 10^{5} /\right.$ well $)$ were placed in 96 -well plates and incubated at $37^{\circ} \mathrm{C}$ with $5 \% \mathrm{CO}_{2}$ for $24 \mathrm{~h}$. Then, different concentrations of samples at 5 to $80 \mu \mathrm{g} / \mathrm{mL}$ (2-fold dilution) were added and incubated for $24 \mathrm{~h}$. Each sample was analyzed in triplicate. After sample incubation, $100 \mu \mathrm{L} /$ well $5 \mathrm{mg} / \mathrm{mL} 0.5 \%$ MTT was added to the wells and incubated for $4 \mathrm{~h}$. When purple precipitate was clearly visible under a microscope, $100 \mu \mathrm{L}$ of DMSO was added, and the plate was shaken for $5 \mathrm{~min}$. The absorbance of each well was measured at $540 \mathrm{~nm}$ with a microtiter plate reader using DMSO as a blank, and percentages of cell viability were calculated:

$$
\begin{aligned}
\text { percentage of cell viability }= & \frac{\text { absorbance of extract treated wells }}{\text { absorbance of untreated wells }} \\
& \times 100 .
\end{aligned}
$$


2.11. Liquid Chromatography-Quadrupole Time-of-Flight Mass Spectrometry (LC-QTOF MS) Conditions. The composition of Tri-TT extract was analyzed by UHPLC with a column from Zorbax Eclipse Plus C18 Rapid Resolution HD column (150 mm length* $2.1 \mathrm{~mm}$ inner diameter, particle size $1.8 \mu \mathrm{m})$, using a liquid chromatograph-quadrupole time-of-flight mass spectrometry (LC-QTOF MS) instrument (1290 Infinity II LC-6545 Quadrupole-TOF, Agilent Technologies, USA). The temperature was maintained at $40^{\circ} \mathrm{C}$, and the injection volume was $2 \mu \mathrm{L}$. Elution was performed with the following $30 \mathrm{~min}$, and mobile phase program was as follows: A: $0.1 \%$ formic acid in water, B: acetonitrile, and flow rate: $0.2 \mathrm{~mL} / \mathrm{min}$. LC-MS/MS analysis was performed in negative ion mode with a scanning range from $\mathrm{m} / \mathrm{z} 100$ to 1500 using a Dual AJS ESI ion source.

2.12. Statistical Analysis. The data are presented as the mean value \pm SD value. One-way ANOVA was conducted. Minitab software was used to calculate the significant differences $(p<0.05)$ between mean values.

\section{Results and Discussion}

3.1. Extract Yield. Our results demonstrated that the yield of the ethanol extract of Tri-TT was $1.489 \%$. The highest extraction yield was found for C. fistula (2.670\%), followed by $P$. dulce and $F$. benjamina (Table 1). This finding was consistent with that of previous studies, showing that alcohol extracts have a good percentage yield [16-18].

3.2. Free Radical Scavenging Activities, DPPH Assay, and ABTS Assay. DPPH and ABTS assays are the most commonly used antioxidant assays and are spectrophotometric techniques based on quenching of stable-colored radicals [18]. The DPPH radical scavenging activity and ABTS radical content of the Tri-TT extract were $0.081 \pm 0.00 \mathrm{mg} / \mathrm{mL}$ and $0.021 \pm 0.00 \mathrm{mg} / \mathrm{mL}$, respectively. For the herbal components, $P$. dulce had remarkable DPPH and ABTS free radical scavenging activities, with $\mathrm{IC}_{50}$ values of $0.07 \pm 0.00$ and $0.10 \pm 0.00 \mathrm{mg} / \mathrm{mL}$, respectively (Table 2). This study is the first to examine the antioxidant capacity of the Tri-TT remedy. A previous study on herbal components showed that the methanol extract of the bark and leaves of $P$. dulce demonstrated antioxidant capacities by the DPPH assay of $150.23 \pm 2.8$ and $250.32 \pm 4.8 \mu \mathrm{g} / \mathrm{mL}$, respectively [16]. The radical scavenging activity determined using the DPPH radical assay yielded $\mathrm{IC}_{50}$ values of $5.20 \pm 0.15,88.29 \pm 2.65$, $87.39 \pm 2.60$, and $96.49 \pm 2.90 \mu \mathrm{g} / \mathrm{mL}$ for petroleum ether, ethyl acetate, aqueous, and methanol extracts of $P$. dulce fruit, respectively [13]. The percentages of inhibition for methanol extracts of $C$. fistula bark at concentrations of 20 , $40,60,80$, and $100 \mu \mathrm{g} / \mathrm{mL}$ were $8.88,27.84,40.11,58.88$, and 85.82, respectively [19]. In addition, the ethanolic $F$. benjamina leaf extract had an inhibition percentage of 44.87 and was usually nontoxic [20]. The DPPH and ABTS assays showed that the $P$. dulce extract had the strongest antioxidant activity, followed by C. fistula and F. benjamina (Table 2). The results of this study were similar to those of
TABLE 1: Ethanol extraction yields of the Tri-Than-Thip remedy and the herbal components.

\begin{tabular}{lc}
\hline Plant materials & Extraction yield $(\mathrm{g} / 100 \mathrm{~g}$ of dried plant materials) \\
\hline Tri-Than-Thip & 1.489 \\
$P$. dulce & 2.223 \\
C. fistula & 2.670 \\
F. benjamina & 2.051 \\
\hline
\end{tabular}

Selvakumar, who reported that the ethanol extract of flowers from these species had an $\mathrm{IC}_{50}$ value of $85.20 \mu \mathrm{g} / \mathrm{mL}$ [21]. The $50 \%$ ethanol extract of $C$. fistula flowers exhibited an antioxidant activity of $47 \%$ at $4 \mu \mathrm{g} / \mathrm{mL}$, and the methanol extract of $F$. benjamina leaves demonstrated higher antioxidant potential with a significant $\mathrm{IC}_{50}$ value of 37.76 at $100 \mu \mathrm{g} / \mathrm{mL}[22,23]$. Based on the antioxidant activity results from the above report, Tri-TT and its herbal components show good potential to control oxidative stress by the DPPH and ABTS assays, but both methods simulate free radical formation at the in vitro level and generate free radicals not found in the body. Therefore, the NBT assay and ORAC assay are important techniques that will confirm the antioxidant capacity of an extract. The superoxide anion radical scavenging activity was estimated by the NBT method [24]. Superoxide radicals are known to be very harmful to cellular components as precursors of more ROS, and the ability of a plant extract to scavenge oxidation and mitigate biological damage is of interest [25]. The superoxide radical scavenging activity was defined as the concentration that produced 50\% inhibition of superoxide anion radicals, as shown in Table 2. The $\mathrm{IC}_{50}$ value of Tri-TT extract was $20.05 \pm 0.057 \mathrm{mg} / \mathrm{mL}$, similar to that of the Triphala remedy, which is a popular tonic drug, and antioxidants from a traditional Ayurvedic herb remedy showed an $\mathrm{IC}_{50}$ value of $42.95 \pm 2.07 \mu \mathrm{g} / \mathrm{mL}$ [26]. The herbal component $C$. fistula showed the best antioxidant activity of $0.08 \pm 0.02 \mathrm{mg} / \mathrm{mL}$. As previously reported, the $\mathrm{IC}_{50}$ values of ethanolic and water C. fistula fruit extracts were compared, and the C. fistula ethanol extract showed the best $\mathrm{NO}$ radical scavenging activity of $1,232.64 \pm 1.73 \mu \mathrm{g} \mathrm{mL}[6]$.

According to the ORAC assay, which has been widely used to investigate the scavenging activities of several natural compounds, hydroxyl radicals are major active oxygen species causing lipid peroxidation and enormous biological damage $[20,27]$. The tested extracts scavenged peroxyl radicals in a concentration-dependent manner, as indicated by the inhibition of fluorescence decay. In this study, C. fistula had remarkable peroxyl radical scavenging properties with an ORAC value of $6.499 \pm 0.67 \mu \mathrm{M} \mathrm{TE} / \mathrm{g}$ extract (Figure 1). A previous report demonstrated that the $\mathrm{IC}_{50}$ value of an ethanolic $C$. fistula extract from flowers showed a better hydroxyl radical scavenging activity $\left(\mathrm{IC}_{50}\right)$ of $609.03 \pm 0.64 \mu \mathrm{g} / \mathrm{mL}$ than that of the aqueous C. fistula fruit extract, which exhibited a moderate activity of $1748.86 \pm 0.65 \mu \mathrm{g} / \mathrm{mL}$. The above activities of the C. fistula ethanol and water extracts clearly indicate strong concentration-dependent activity [6], and it may be concluded that C. fistula was the main component of Tri-TT involved in preventing and reducing intracellular ROS levels. 
TABLE 2: Metal chelating activity (MCA) and free radical scavenging capacities of different extracts of Tri-Than-Thip and three botanical extracts.

\begin{tabular}{lcccc}
\hline \multirow{2}{*}{ Extracts } & MCA assay $\left(\mathrm{IC}_{50} ; \mathrm{mg} / \mathrm{mL}\right)^{*}$ & \multicolumn{3}{c}{ Radical scavenging properties $\left(\mathrm{IC} \mathrm{C}_{50} ; \mathrm{mg} / \mathrm{mL}\right)^{* *}$} \\
& & DPPH & ABTS & NBT \\
\hline Tri-TT & $0.02 \pm 0.00$ & $0.08 \pm 0.00$ & $0.02 \pm 0.00$ & $0.205 \pm 0.057$ \\
P. dulce & $0.01 \pm 0.00^{\mathrm{b}}$ & $0.07 \pm 0.00^{\mathrm{a}}$ & $0.01 \pm 0.00^{\mathrm{a}}$ & $0.33 \pm 0.23^{\mathrm{b}}$ \\
C. fistula & $0.02 \pm 0.00^{\mathrm{c}}$ & $0.10 \pm 0.00^{\mathrm{a}}$ & $0.01 \pm 0.00^{\mathrm{a}}$ & $0.08 \pm 0.02^{\mathrm{a}}$ \\
F. benjamina & $0.01 \pm 0.00^{\mathrm{a}}$ & $1.69 \pm 1.79^{\mathrm{b}}$ & $0.06 \pm 0.01^{\mathrm{b}}$ & $1.06 \pm 0.25^{\mathrm{c}}$ \\
\hline
\end{tabular}

${ }^{*} \mathrm{IC}_{50}$ of EDTA (a positive control) was $0.01 \pm 0.00 \mathrm{mg} / \mathrm{mL}$. ${ }^{* *}$ The $\mathrm{IC}_{50}$ values of Trolox obtained from the DPPH, ABTS, and NBT assays were $0.025,0.020$, and $0.025 \mathrm{mg} / \mathrm{mL}$, respectively. ${ }^{\mathrm{a}-\mathrm{c}}$ Values in the same column with different superscripts are significantly different $(p<0.05)$. Extraction yield $(\mathrm{g} / 100 \mathrm{~g}$ dried plant material).

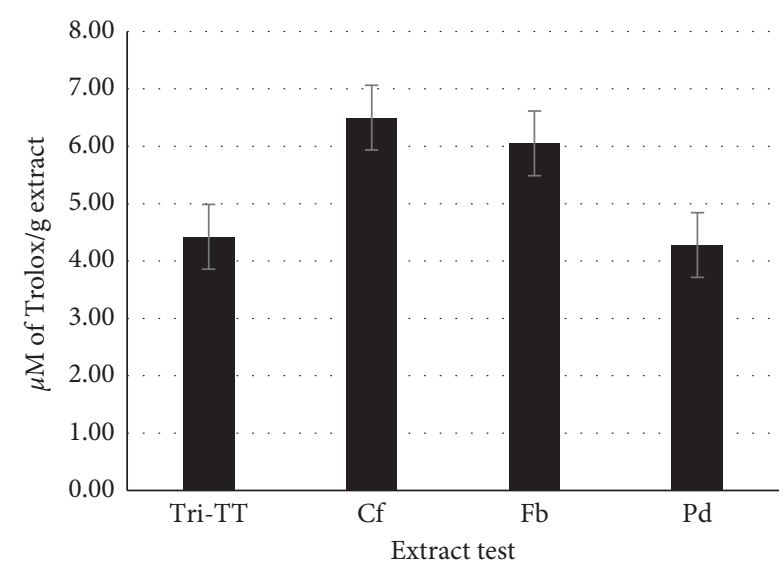

Figure 1: Effects of Tri-Than-Thip (Tri-TT), Cassia fistula (Cf), Ficus benjamina $(\mathrm{Fb})$, and Pithecellobium dulce $(\mathrm{Pd})$ ethanol extracts on the production of peroxyl radicals. All values are presented as the means $\pm \mathrm{SD}$. Bars with different letters indicate statistically significant differences among groups at $p<0.05$ by oneway ANOVA.

\subsection{In Vitro Metal Chelating and FRAP Radical Scavenging} Activity. The FRAP assay is relatively simple and easy to conduct. The FRAP assay measures the potential of antioxidants to reduce the ferric tripyridyl triazine (Fe3+-TPTZ) complex and produce a blue ferrous complex [27]. The ability of a compound to reduce iron(III) to iron(II) generally depends on the presence of reductants [28], which exhibit antioxidative potential by quenching the free radical chain and donating a hydrogen atom $[29,30]$. The results (Table 2) indicated that Tri-TT had the highest MCA with an $\mathrm{IC}_{50}$ value of $0.02 \pm 0.00 \mathrm{mg} / \mathrm{mL}$. The ion-chelating effect increased with increasing concentrations and stimulated a remarkable reducing power, with an FRAP value of $1,919.71 \pm 63.14 \mathrm{mM} \mathrm{FeSO}_{4} / \mathrm{mg}$ (Table 3 ). The value in this study was higher than that reported in a previous study on traditional Thai remedies. Ya-hom Intajak and Jatu-PhalaTiga remedies had FRAP values of $0.93 \pm 0.12\left(\mathrm{mmol} \mathrm{FeSO}_{4} /\right.$ g) and $23.07 \pm 1.84\left(\mathrm{mM} \mathrm{FeSO}_{4} / \mathrm{mg}\right)$, respectively $[4,31]$. In addition, $P$. dulce possessed the highest reducing power, with an FRAP value of 3,335.38 $\pm 439.75 \mathrm{mMFeSO}_{4} / \mathrm{mg}$, whereas its MCA IC 50 value was $0.01 \pm 0.00 \mathrm{mg} / \mathrm{mL}$. Previous reports showed that the FRAP $\mathrm{IC}_{50}$ value of a $P$. dulce methanol extract was $13.70 \mu \mathrm{g} / \mathrm{mL}$ [7] and that the extract possessed antioxidant, antibacterial, and antifungal activities [32]. Thus, it was found that Tri-TT extract was a good choice for antioxidant use according to the FRAP and MCA assay results.

3.4. TPC and TF Contents. TPC and TF contents are indicators widely used to represent antioxidant activity. The high potential of phenolic and flavonoid compounds to scavenge radicals may be explained by their phenolic hydroxyl groups [33]. This study determined the TPC and TF contents of the Tri-TT remedy and individual botanical extracts. The TPC contents and TF contents were $287.87 \pm 15.10 \mathrm{mg}$ equivalence/g extract and $225.62 \pm 2.056 \mathrm{mg}$ catechin equivalent/g extract, respectively. In recent years, researchers have been interested in the search for new, natural antioxidants. Tri-TT has good antioxidant properties, similar to Tri-phal, Trichin-Tha-La-Ma-Ka, Tri-Ke-Son-Mat, Tri-Sa-Mo, Tri-Ti-PaYa-Ros, and Tri-Su-Ra-Pon, and previous studies have described Tri-TT as the best antioxidant source among Triremedy groups from Thai folk medicine $[3,19]$. In addition. Tri-TT has higher TPC and TF contents than Ya-hom Intajak and twenty polyherbal remedies either with rejuvenating effects or that are used as health-promoting tonics $[31,34]$. This study detected significant differences $(p>0.05)$ in the TPC contents of the three botanical extracts and showed that $P$. dulce had the highest TPC content, similar to the methanol extract of leaves and bark, which exhibited a TPC content of $0.084 \pm 0.240 .129 \pm 0.11 \mu \mathrm{g} / \mathrm{mL}$ gallic acid equivalents [16]. The C. fistula extract exhibited the highest TF content, consistent with a previous study that reported TF contents of methanolic $C$. fistula leaf and stem extracts of $45.08 \pm 1.37$ and $4.17 \pm 0.20$ (quercetin equivalent) $\mathrm{mg} / \mathrm{g}$ extracted compound, respectively [35]. In 2002, researchers reported the TPC and TF contents of several parts of C. fistula, including young leaves, old leaves, twigs, bark, flower buds, flowers, and pods [36], but this study showed that the roots have higher TPC and TF contents (Table 3). From all the experimental reports above, the results differed due to differences in the reactions and mechanisms of the methods used, which should be considered when comparing the antioxidant activities of plant extracts and compounds in herbs [37].

3.5. Cytotoxicity Analysis by the MTT Assay. Vero cells, also known as African green monkey kidney cells, are recognized by the World Health Organization (WHO) and Chinese Pharmacopoeia in producing vaccines [38]. In the present 
TABLE 3: Ferric-reducing antioxidant power (FRAP), total phenolic compound content, and total flavonoid content of different extracts of Tri-Than-Thip and its three botanical constituents.

\begin{tabular}{lcrr}
\hline \multirow{2}{*}{ Extracts } & \multirow{2}{*}{ FRAP assay $\left(\mathrm{mM} \mathrm{FeSO}_{4} / \mathrm{mg}\right)$} & \multicolumn{2}{c}{ Total contents (mg equivalent/g of extract) } \\
& & Phenolic compounds & Flavonoids \\
\hline Tri-TT & $1919.71 \pm 63.14$ & $287.87 \pm 15.10$ & $225.62 \pm 2.056$ \\
P. dulce & $3335.38 \pm 439.75^{\mathrm{a}}$ & $368.43 \pm 4.71^{\mathrm{a}}$ & $152.02 \pm 46.80^{\mathrm{b}}$ \\
C. fistula & $1132.89 \pm 129.17^{\mathrm{b}}$ & $278.87 \pm 7.03^{\mathrm{b}}$ & $238.33 \pm 16.65^{\mathrm{a}}$ \\
F. benjamina & $350.26 \pm 10.77^{\mathrm{c}}$ & $66.96 \pm 4.77^{\mathrm{c}}$ & $72.89 \pm 6.17^{\mathrm{c}}$ \\
\hline
\end{tabular}

${ }^{a-c}$ Values in the same column with different superscripts are significantly different $(p<0.05)$.

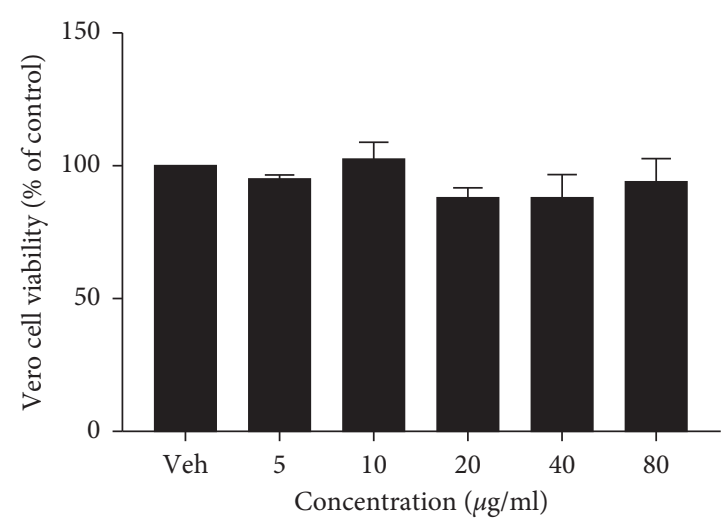

(a)

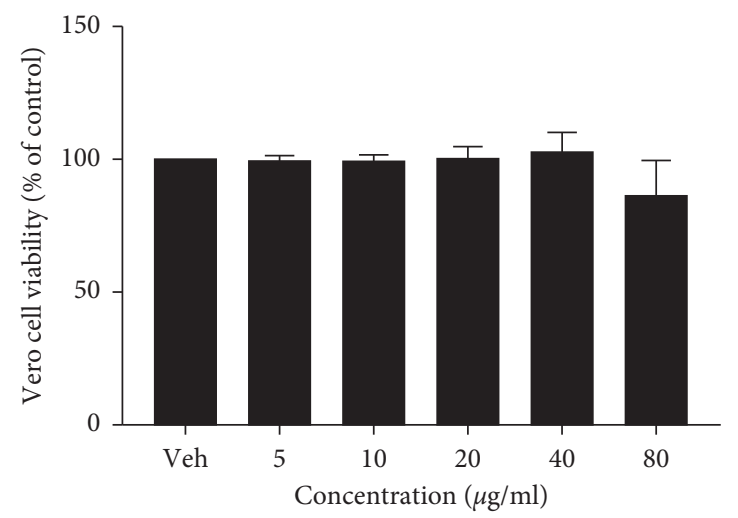

(c)

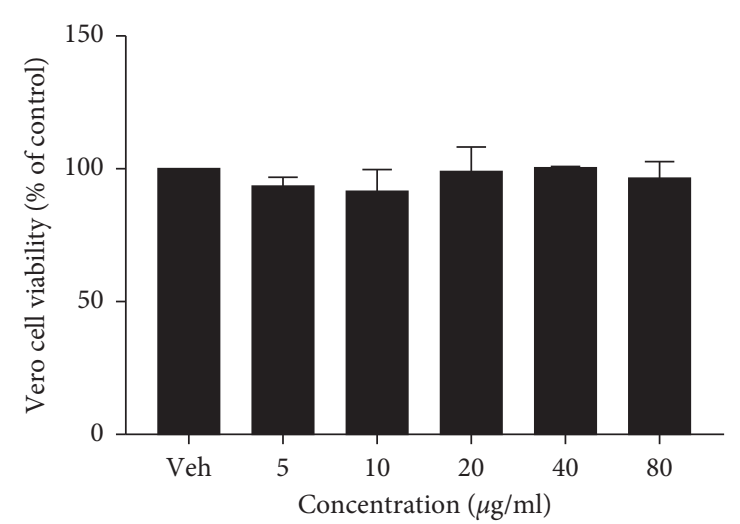

(b)

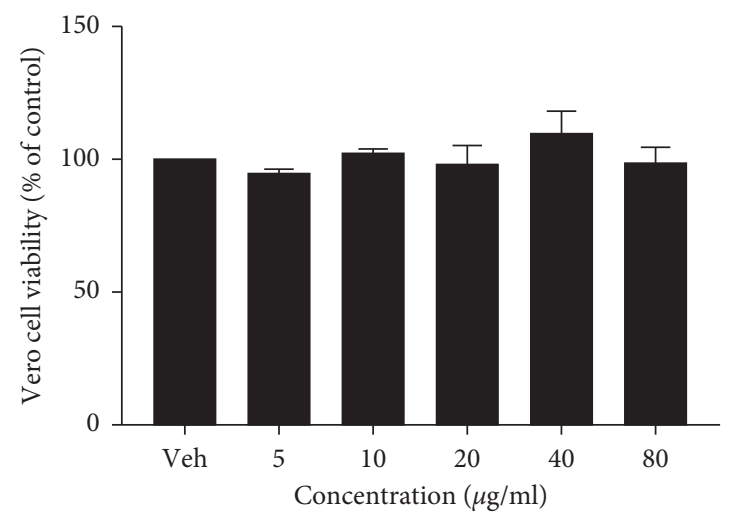

(d)

Figure 2: Cytotoxicity of Tri-TT (a), Ficus benjamina (b), Cassia fistula (c), and Pithecellobium dulce (d) extracts on Vero cells. The value was from three replicates $(n=3)$.

study, the cytotoxic effects of extracts of Tri-TT and its three botanical extracts were determined by the MTT assay. Figure 2 shows the viability of Vero cells after treatment with various concentrations of the extracts of Tri-TT and its three botanical extracts. The $\mathrm{IC}_{50}$ value indicated the concentration that can inhibit 50\% cell proliferation and showed that the extracts had cytotoxic ability. A relatively high $\mathrm{IC}_{50}$ means that the compound is more nontoxic to the cell. Similar to a previous report about three-component herbal remedies, Vero cells were exposed to quercetin 3-O-rutinoside, kaempferol 3-Orutinoside, and kaempferol 3-O-robinobioside from the ethanol extract of F. Benjamina leaves, and antiviral activity was evaluated by the plaque assay and exhibited low toxicity [39]. In addition to normal cell testing, herbal components have also been found to inhibit cancer cells and have shown varying activities from toxic to safe. $P$. dulce bark and leaf lipophilic fractions were assessed for their cytotoxic activity using an MTT cell viability assay against two different cancer cell lines, namely, hepatocellular carcinoma and colon carcinoma cells, and the lipophilic extract was reported to possess significant cytotoxic activity in a colon carcinoma cancer line [40], and it was shown that there was cytotoxic potential of $P$. dulce 
TABLE 4: Compounds identified in the Tri-TT remedy by LC-QTOF-MS.

\begin{tabular}{|c|c|c|c|c|c|}
\hline No. & $\mathrm{M} / \mathrm{Z}$ & $\mathrm{RT}(\min )$ & Compounds & Molecular formula & Molecular weight \\
\hline 1 & 243.07 & 10.14 & $3,3^{\prime}, 4,5^{\prime}$-Tetrahydroxy-trans-stilbene & $\mathrm{C}_{14} \mathrm{H}_{12} \mathrm{O}_{4}$ & 244.07 \\
\hline 2 & 561.14 & 8.52 & $3,3^{\prime}, 4^{\prime}, 5,7$-Pentahydroxyflavan(4->8)-3,4',5,7-tetrahydroxyflavan & $\mathrm{C}_{30} \mathrm{H}_{26} \mathrm{O}_{11}$ & 562.15 \\
\hline 3 & 419.14 & 13.82 & $2^{\prime}, 4^{\prime}, 6^{\prime}$-Trihydroxydihydrochalcone $4^{\prime}$-glucoside & $\mathrm{C}_{21} \mathrm{H}_{24} \mathrm{O}_{9}$ & 420.14 \\
\hline 4 & 285.04 & 12.36 & Luteolin & $\mathrm{C}_{15} \mathrm{H}_{10} \mathrm{O}_{6}$ & 286.05 \\
\hline 5 & 263.09 & 9.79 & $1^{\prime}$-Acetoxyeugenol acetate & $\mathrm{C}_{14} \mathrm{H}_{16} \mathrm{O}_{5}$ & 264.10 \\
\hline 6 & 269.05 & 19.78 & Baicalein & $\mathrm{C}_{15} \mathrm{H}_{10} \mathrm{O}_{5}$ & 270.05 \\
\hline 7 & 269.08 & 18.22 & Cardamonin & $\mathrm{C}_{16} \mathrm{H}_{14} \mathrm{O}_{4}$ & 270.09 \\
\hline 8 & 109.03 & 5.62 & Hydroquinone & $\mathrm{C}_{6} \mathrm{H}_{6} \mathrm{O}_{2}$ & 110.04 \\
\hline 9 & 269.05 & 13.71 & Apigenin & $\mathrm{C}_{15} \mathrm{H}_{10} \mathrm{O}_{5}$ & 270.05 \\
\hline 10 & 271.06 & 13.74 & $(-)$-Naringenin & $\mathrm{C}_{15} \mathrm{H}_{12} \mathrm{O}_{5}$ & 272.07 \\
\hline 11 & 477.07 & 7.82 & Quercetin $3^{\prime}$-O-glucuronide & $\mathrm{C}_{21} \mathrm{H}_{18} \mathrm{O}_{13}$ & 478.08 \\
\hline 12 & 191.06 & 2.05 & Quinic acid & $\mathrm{C}_{7} \mathrm{H}_{12} \mathrm{O}_{6}$ & 192.06 \\
\hline 13 & 289.07 & 6.76 & Epicatechin & $\mathrm{C}_{15} \mathrm{H}_{14} \mathrm{O}_{6}$ & 290.08 \\
\hline 14 & 285.04 & 14.01 & Kaempferol & $\mathrm{C}_{15} \mathrm{H}_{10} \mathrm{O}_{6}$ & 286.05 \\
\hline 15 & 283.06 & 17.43 & Genkwanin & $\mathrm{C}_{16} \mathrm{H}_{12} \mathrm{O}_{5}$ & 284.07 \\
\hline 16 & 255.07 & 17.43 & Pinocembrin & $\mathrm{C}_{15} \mathrm{H}_{12} \mathrm{O}_{4}$ & 256.07 \\
\hline 17 & 169.01 & 3.93 & Gallic acid & $\mathrm{C}_{7} \mathrm{H}_{6} \mathrm{O}_{5}$ & 170.02 \\
\hline 18 & 137.02 & 6.98 & 3,4-Dihydroxybenzaldehyde & $\mathrm{C}_{7} \mathrm{H}_{6} \mathrm{O}_{3}$ & 138.03 \\
\hline 19 & 305.07 & 6.19 & Epigallocatechin & $\mathrm{C}_{15} \mathrm{H}_{14} \mathrm{O}_{7}$ & 306.07 \\
\hline 20 & 471.35 & 20.57 & Corosolic acid & $\mathrm{C}_{30} \mathrm{H}_{48} \mathrm{O}_{4}$ & 472.35 \\
\hline 21 & 301.00 & 9.05 & Ellagic acid & $\mathrm{C}_{14} \mathrm{H}_{6} \mathrm{O}_{8}$ & 302.01 \\
\hline 22 & 463.09 & 8.97 & Quercetin 3-galactoside & $\mathrm{C}_{21} \mathrm{H}_{20} \mathrm{O}_{12}$ & 464.10 \\
\hline 23 & 471.35 & 23.28 & Maslinic acid & $\mathrm{C}_{30} \mathrm{H}_{48} \mathrm{O}_{4}$ & 472.35 \\
\hline 24 & 305.18 & 17.56 & Capsiate & $\mathrm{C}_{18} \mathrm{H}_{26} \mathrm{O}_{4}$ & 306.18 \\
\hline 25 & 301.07 & 14.09 & Hesperetin & $\mathrm{C}_{16} \mathrm{H}_{14} \mathrm{O}_{6}$ & 302.08 \\
\hline
\end{tabular}

leaf extracts on breast cancer cells (MCF-7 cell line) at $400 \mathrm{mg} / \mathrm{mL}$ [41]. In addition, a C. fistula methanol extract reduced prostate human cancer cell line viability in a dosedependent manner in the MTT assay. The lowest viability of cancer cells was observed with $30 \mu \mathrm{g}$, at $5.06 \%$, and the vehicle control showed $97.77 \%$ cell viability [42].

\subsection{Liquid Chromatography-Quadrupole Time-of-Flight Mass} Spectrometry (LC-QTOF-MS) Conditions. The qualitative analysis of compounds in the Tri-TT remedy infusion using LC-QTOF-MS in negative mode revealed chemical constituents and the known antioxidant-related constituents, with phenolic acids and flavonoids being the major components. Within the phenolic acid group, catechins such as epicatechin $(\mathrm{RT}=6.76)$ and epigallocatechin $(\mathrm{RT}=6.19)$ were identified, and flavonoids, one of the most widespread groups of plant phenolics, were the main class of compounds characterized in samples and included baicalein $(\mathrm{RT}=19.78), \quad$ genkwanin $\quad(\mathrm{RT}=17.43), \quad(-)$-naringenin $(\mathrm{RT}=13.74), \quad$ pinocembrin $\quad(\mathrm{RT}=17.43), \quad$ hesperetin $(\mathrm{RT}=14.09)$, luteolin $(\mathrm{RT}=12.36)$, apigenin $(\mathrm{RT}=13.71)$, quercetin 3 '-O-glucuronide $(\mathrm{RT}=7.28)$, quinic acid $(\mathrm{RT}=2.05)$, and gallic acid $(\mathrm{RT}=3.93)$. The other detected compounds were $3,3^{\prime}, 4,5^{\prime}$-tetrahydroxy-trans-stilbene $(\mathrm{RT}=10.14), 3,3^{\prime}, 4^{\prime}, 5,7$-pentahydroxyflavan $(4->8)-3,4^{\prime}, 5,7$ tetrahydroxyflavan $(\mathrm{RT}=8.52)$, and other chemicals in Table 4. The LC-QTOF-MS analysis showed a high content of flavonoids, which have a very strong antioxidant ability. Flavonoids are the main class of phenolic compounds responsible for antioxidant and free radical scavenging properties. Previous studies on the chemical GC-MS analysis of methanol extracts of $F$. benjamina from leaves and bark identified 28 alkaloids in leaves and 14 alkaloids in bark. A positive correlation with total alkaloid content was observed, suggesting that the level of antioxidant activity in this species is strongly correlated to the alkaloid content [43]. Other parts of F. benjamina (stems and roots) contained antioxidant-related chemical constituents, such as methenamine $(\mathrm{RT}=2.297)$, hexadecanoic acid $(\mathrm{RT}=10.26)$, methyl-2phenylindole $\quad(\mathrm{RT}=10.63), 9,12$-octadecadienoic acid $(\mathrm{RT}=11.91)$, and palmitic acid $(\mathrm{RT}=11.04)$ [5]. The chemical screening of the marker components in the fruit of C. fistula by HPLC showed the chemical structure of 14 compounds, for example, catechin $(\mathrm{RT}=13.057)$, epicatechin $(\mathrm{RT}=16.667)$, quercitrin $(\mathrm{RT}=42.038)$, rutin $(\mathrm{RT}=29.601)$, sennoside $\mathrm{B} \quad(\mathrm{RT}=36.768)$, sennoside A $(\mathrm{RT}=42.479)$, and rhein $(\mathrm{RT}=89.860)$ [44]. The last herb component, $P$. dulce, contained many chemical groups with antioxidant effects that were similar to those of the two previous herbs, such as glycosylated compounds and flavonoids (quercetin-3-glucoside, luteolin-7-O-glucoside, and kaempferol-3-O-rhamnoside) as well as fatty acids (azelaic acid, etc.) [45]. The chemicals found in the herbal components and Tri-TT remedy belonged to similar chemical groups as the primary and secondary metabolite constituents of plant parts, with an emphasis on phenolic compounds and flavonoids with potent antioxidant activities (Figure 3). This paper also assessed the antioxidant and free radical abilities of plant parts. 
3,3',4,5'-Tetrahydroxy-trans-stilbene<smiles>Oc1cc(O)cc(C=Cc2ccc(O)c(O)c2)c1</smiles>

Luteolin<smiles>Oc1cc(O)c2c(c1)OC(c1ccc(O)c(O)c1)=CC2O</smiles>

1'-Acetoxyeugenol acetate<smiles>CC[C@H](OC(C)=O)c1ccc(OC(C)=O)c(OC)c1</smiles><smiles>O=c1cc(-c2ccccc2)oc2cc(O)c(O)c(O)c12</smiles>

Apigenin<smiles>O=c1cc(-c2ccc(O)cc2)oc2cc(O)cc(O)c12</smiles><smiles>COc1cc(O)cc(O)c1C(=O)CCc1ccccc1</smiles>

(-)-Naringenin<smiles>O=C1C[C@H](c2ccc(O)cc2)Oc2cc(O)cc(O)c21</smiles>

FIgURE 3: Chemical structure of eight compounds tentatively identified by LC-QTOF-MS.

\section{Conclusions}

This study showed that the Tri-TT remedy and its three botanical constituents have complicated chemical constituents according to LC-QTOF-MS fingerprint analysis, as well as remarkable antioxidant, superoxide radical scavenging, hydroxyl radical scavenging, cytotoxic and protective activities against induced oxidative stress in the body. The ethanol extract of Tri-TT could be a significant material for the prevention of several diseases and could be 
considered a good antioxidant source in the pharmaceutical industry.

\section{Data Availability}

The data that support the findings of this study are available on request from the corresponding author.

\section{Conflicts of Interest}

The authors declare that they have no conflicts of interest.

\section{Acknowledgments}

The authors are very grateful to Walailak University, Nakhon Si Thammarat, Thailand, for providing the laboratory facilities. This work was supported by the Research Institute for Health Science, Walailak University, (WU-IRG64-030).

\section{References}

[1] V. Lobo, A. Patil, A. Phatak, and N. Chandra, "Free radicals, antioxidants and functional foods: impact on human health," Pharmacognosy Reviews, vol. 4, no. 8, pp. 118-126, 2010.

[2] F. J. Hidalgo and R. Zamora, "Food processing antioxidants," Advances in Food and Nutrition Research, vol. 81, pp. 31-64, 2017.

[3] S. Chusri, P. Singthong, and T. Kaewmanee, "Antioxidant, anticancer, and cytotoxic effects of Thai traditional herbal preparations consumed as rejuvenators," CyTA - Journal of Food, vol. 13, no. 1, pp. 31-64, 2015.

[4] P. Wetchakul, J. A. Goon, A. E. Adekoya et al., "Traditional tonifying polyherbal infusion, Jatu-Phala-Tiga, exerts antioxidant activities and extends lifespan of Caenorhabditis elegans," BMC Complementary and Alternative Medicine, vol. 19, no. 1, pp. 209-211, 2019.

[5] M. Imran, N. Rasool, K. Rizwan et al., "Chemical composition and biological studies of Ficus benjamina," Chemistry Central Journal, vol. 8, no. 1, pp. 12-10, 2014.

[6] R. Abid, R. Mahmood, K. P. Rajesh, and B. E. Kumara Swamy, "Potential in vitro antioxidant and protective effect of Cassia fistula Linn. fruit extracts against induced oxidative damage in human erythrocytes," International Journal of Pharmacy and Pharmaceutical Sciences, vol. 6, no. 9, pp. 497-505, 2014.

[7] S. Kumari, "Evaluation of phytochemical analysis and antioxidant and antifungal activity of Pithecellobium dulce leaves' extract," Evaluation, vol. 10, no. 1, pp. 370-375, 2017.

[8] A. Ghasemi Pirbalouti, A. Siahpoosh, M. Setayesh, L. Craker, and L. Craker, "Antioxidant activity, total phenolic and flavonoid contents of some medicinal and aromatic plants used as herbal teas and condiments in Iran," Journal of Medicinal Food, vol. 17, no. 10, pp. 1151-1157, 2014.

[9] A. Chew, M. K. Muhammed, and S. Ramsha, "Comparatives analysis of phenolic, flavonoids and antioxidant and antibacterial potential of methanolic, hexanic and aqueous extracts from Adiantum caudatum leaves," Antioxidants, vol. 4, pp. 393-409, 2000.

[10] M. Alam, A. S. Juraimi, M. Y. Rafii et al., "Evaluation of antioxidant compounds, antioxidant activities, and mineral composition of 13 collected purslane (Portulaca oleracea L.) accessions," BioMed Research International, vol. 2014, Article ID 296063, 10 pages, 2014.
[11] M. Fontana, L. Mosca, and M. A. Rosei, "Interaction of enkephalins with oxyradicals11Abbreviations: ABAP, 2,2' azobis(2-amidinopropane); dopa, dihydroxyphenyl-alanine; $\mathrm{H} 2 \mathrm{O} 2$, hydrogen peroxide; leu-enk, leu-enkephalin; metenk, met-enkephalin; $\mathrm{LOOH}$, linoleic acid 13-hydroperoxide; NBT, nitro blue tetrazolium; PMS, phenazine methosulfate; ROS, reactive oxygen species; SOD, superoxide dismutase; TBARS, thiobarbituric acid reactive substances," Biochemical Pharmacology, vol. 61, no. 10, pp. 1253-1257, 2001.

[12] M. K. Roy, M. Koide, T. P. Rao, T. Okubo, Y. Ogasawara, and L. R. Juneja, "ORAC and DPPH assay comparison to assess antioxidant capacity of tea infusions: relationship between total polyphenol and individual catechin content," International Journal of Food Sciences and Nutrition, vol. 61, no. 2, pp. 109-124, 2010.

[13] B. Sultana, F. Anwar, and R. Przybylski, “Antioxidant activity of phenolic components present in barks of Azadirachta indica, Terminalia arjuna, Acacia nilotica, and Eugenia jambolana Lam. trees," Food Chemistry, vol. 104, no. 3, pp. 1106-1114, 2007.

[14] A. G. R. Jose, B. Govindarajulu, T. Abirami, V. Kavitha, G. Saritha, and J. Karthikeyan, "In vitro antioxidant and cytotoxic activity of ethanol bark extract of Madhuca longifolia on MCF-7 and Vero cell lines," Journal of Pharmacognosy and Phytochemistry, vol. 7, no. 6, pp. 1368-1371, 2018.

[15] D. Naresh, D. Bharne, P. Saikia, and V. Vindal, "Anthraquinone rich Cassia fistula pod extract induces IFIT1, antiviral protein," NISCAIR Online Periodicals Repository, vol. 17, no. 3, pp. 474-479, 2018.

[16] S. D. Katekhaye and M. S. Kale, "Antioxidant and free radical scavenging activity of Pithecellobium dulce (Roxb.) Benth wood bark and leaves," Free Radicals and Antioxidants, vol. 3, no. 2, pp. 47-57, 2012.

[17] S. Panda, L. Padhi, and G. Mohanty, "Antibacterial activities and phytochemical analysis of Cassia fistula (Linn.) leaf," Journal of Advanced Pharmaceutical Technology \& Research, vol. 2, no. 1, pp. 62-67, 2011.

[18] W. Sujarwo and A. P. Keim, "Spondias pinnata (L. f.) Kurz. (Anacardiaceae): profiles and applications to diabetes," in Bioactive Food as Dietary Interventions for Diabetes, pp. 395-405, Academic Press, Cambridge, MA, USA, 2019.

[19] R. Jeeva and N. Srinath, "Evaluation of antioxidant potentirl of Cassia fistula (Linn.) bark extract," Kongunadu Research Journal, vol. 3, no. 1, pp. 76-80, 2016.

[20] N. M. Saptarini and I. E. Herawati, "Comparative antioxidant activity on the Ficus benjamina and Annona reticulata leaves," International Journal of Public Health Science, vol. 4, no. 1, pp. 21-26, 2015.

[21] M. Selvakumar, P. Palanichamy, and V. Arumugam, "In silico potential of nutraceutical plant of Pithecellobium dulce against GRP78 target protein for breast cancer," Applied Nanoscience, vol. 3, no. 2, pp. 1-13, 2021.

[22] P. Limtrakul, S. Yodkeeree, P. Thippraphan, W. Punfa, and J. Srisomboon, "Anti-aging and tyrosinase inhibition effects of Cassia fistula flower butanolic extract," BMC Complementary and Alternative Medicine, vol. 16, no. 1, pp. 497-499, 2016.

[23] B. S. Ramesh, "Comparative evaluation of antioxidant and hemolytic potential of ornamental plants Ficus benjamina, Antigonon leptopus, and Amaranthus tricolor," International Journal of Green Pharmacy, vol. 14, no. 1, 2020.

[24] I. Gülçin, Z. Huyut, M. Elmastaş, and H. Y. Aboul-Enein, "Radical scavenging and antioxidant activity of tannic acid," Arabian Journal of Chemistry, vol. 3, pp. 43-53, 2010. 
[25] L. W. Aurand, N. H. Giddings, and G. G. Gidding, "Superoxide and singlet oxygen in milk lipid peroxidation," Journal of Dairy Science, vol. 60, no. 3, pp. 363-369, 1977.

[26] D. Babu, P. Gurumurthy, S. K. Borra, and K. M. Cheria, "Antioxidant and free radical scavenging activity of triphala determined by using different in vitro models," Journal of Medicinal Plants Research, vol. 7, no. 39, pp. 2898-2905, 2013.

[27] A. S. Choudhari, S. A. Suryavanshi, H. Ingle, and R. KaulGhanekar, "Evaluating the antioxidant potential of aqueous and alcoholic extracts of Ficus religiosa using ORAC assay and assessing their cytotoxic activity in cervical cancer cell lines," Biotechnology, Bioinformatics and Bioengineering, vol. 1, no. 4, pp. 443-450, 2011.

[28] I. F. F. Benzie and J. J. Strain, "The ferric reducing ability of plasma (FRAP) as a measure of "antioxidant power": the FRAP assay," Analytical Biochemistry, vol. 239, no. 1, pp. 70-76, 1996.

[29] P.-D. Duh, Y.-Y. Tu, and G.-C. Yen, "Antioxidant activity of water extract of harng jyur (Chrysanthemum morifolium ramat)," Lebensmittel-Wissenschaft und -Technologie- Food Science and Technology, vol. 32, no. 5, pp. 269-277, 1999.

[30] M. H. Gordon, "The mechanism of antioxidant action in vitro," in Food Antioxidants, pp. 1-18, Springer, Dordrecht, Netherlands, 1990.

[31] J. Tuekaew, N. Siriwatanametanon, Y. Wongkrajang, R. Temsiririrkkul, and I. Jantan, "Evaluation of the antioxidant activities of Ya-hom Intajak, a Thai herbal formulation, and its component plants," Tropical Journal of Pharmaceutical Research, vol. 13, no. 9, pp. 1477-1485, 2014.

[32] T. A. Sukantha, K. S. Sripathi, N. T. Ravindran, and P. Balashanmugam, "Evaluation of in vitro antioxidant and antibacterial activity of Pithecellobium dulce Benth fruit peel," International Journal of Current Research, vol. 3, no. 1, pp. 378-382, 2011.

[33] T. Sawa, M. Nakao, T. Akaike, K. Ono, and H. Maeda, "Alkylperoxyl radical-scavenging activity of various flavonoids and other phenolic compounds: implications for the anti-tumor-promoter effect of vegetables," Journal of Agricultural and Food Chemistry, vol. 47, no. 2, pp. 397-402, 1999.

[34] W. Chanthasri, N. Puangkeaw, N. Kunworarath et al., "Antioxidant capacities and total phenolic contents of 20 polyherbal remedies used as tonics by folk healers in Phatthalung and Songkhla provinces, Thailand," BMC Complementary and Alternative Medicine, vol. 18, no. 1, pp. 73-11, 2018.

[35] M. Kaneria and Y. Baravalia, "Antioxidant and antimicrobial properties of various polar solvent extracts of stem and leaves of four Cassia species," African Journal of Biotechnology, vol. 11, no. 10, pp. 2490-2503, 2012.

[36] A. Luximon-Ramma, T. Bahorun, M. A. Soobrattee, and O. I. Aruoma, "Antioxidant activities of phenolic, proanthocyanidin, and flavonoid components in extracts of Cassia fistula," Journal of Agricultural and Food Chemistry, vol. 50, no. 18, pp. 5042-5047, 2002.

[37] S. Wong, L. Leong, and J. Williamkoh, "Antioxidant activities of aqueous extracts of selected plants," Food Chemistry, vol. 99, no. 4, pp. 775-783, 2006.

[38] Y. K. Y. Yasumura, "Studies on SV40 in tissue culture-preliminary step for cancer research in vitro," Nihon rinsho, vol. 21, pp. 1201-1215, 1963.

[39] L. Yarmolinsky, M. Huleihel, M. Zaccai, and S. Ben-Shabat, "Potent antiviral flavone glycosides from Ficus benjamina leaves," Fitoterapia, vol. 83, no. 2, pp. 362-367, 2012.

[40] W. M. Elkady and I. M. Ayoub, "Chemical profiling and antiproliferative effect of essential oils of two Araucaria species cultivated in Egypt," Industrial Crops and Products, vol. 118, pp. 188-195, 2018.

[41] M. Sharma, "Selective cytotoxicity and modulation of apoptotic signature of breast cancer cells byPithecellobium dulceleaf extracts," Biotechnology Progress, vol. 32, no. 3, pp. 756-766, 2016.

[42] A. Kulkarni, M. Ramachandra, Y. L. Ramachandra, and P. Koka, "GC-MS analysis of methanol extract of Cassia fistula and its in vitro anticancer activity on human prostate cancer cell line," Indo American Journal of Pharmaceutical Research, vol. 5, no. 2, pp. 937-944, 2015.

[43] S. Novelli, C. Lorena, and C. Antonella, "Identification of alkaloid's profile in Ficus benjamina L. Extracts with higher antioxidant power," American Journal of Plant Sciences, vol. 05, no. 26, pp. 4029-4039, 2014.

[44] J. Tan, M. Zheng, S. Duan et al., "Chemical profiling and screening of the marker components in the fruit of Cassia fistula by HPLC and UHPLC/LTQ-Orbitrap MSn with chemometrics," Molecules, vol. 23, no. 7, p. 1501, 2018.

[45] N. Romero, C. Areche, J. Cubides-Cárdenas et al., "In vitro anthelmintic evaluation of Gliricidia sepium, Leucaena leucocephala, and Pithecellobium dulce: fingerprint analysis of extracts by UHPLC-orbitrap mass spectrometry," Molecules, vol. 25 , no. 13, pp. 1-17, 2020. 